\title{
Assessing the Evolution of Maritime Strategy in the Asia Pacific
}

\author{
Buddy Suseto ${ }^{1}$, Zarina Othman ${ }^{2}$, Farizal Mohd Razalli ${ }^{3}$ \\ ${ }^{1}$ Faculty of Humanities and Social Sciences, Universiti Kebangsaan Malaysia (email: budiseto@ymail.com) \\ ${ }^{2}$ Corresponding Author. Faculty of Humanities and Social Sciences, Universiti Kebangsaan Malaysia \\ (email: zaiothman02@gmail.com) \\ ${ }^{3}$ Faculty of Humanities and Social Sciences, Universiti Kebangsaan Malaysia (email: farizal@ukm.edu.my)
}

\begin{abstract}
The end of the Cold War has provided an opportunity for scholars to do an in-depth study on the concept of maritime security, especially in the Asia Pacific region. One of the most important but often neglected concepts is maritime strategy which has been developing for centuries. Maritime strategy is designed for states' survival and to protect their national interests. Nevertheless there is no 'one size fits all' concept. Therefore, the purpose of this article is to analyse the similarities and differences between continental states such as the United States, and India, and maritime states such as Indonesia, Japan, Australia, and Singapore in implementing their maritime strategy. In an attempt to present the results, we have reviewed secondary data mainly from the literature written by scholars in the field. Preliminary findings suggests that countries, either continental or maritime states, designed their maritime strategy for national security reasons. States aim to survive in the unknown international political arena. However, domestic and socioeconomic factors such as economic growth, geostrategic interest as well as nature of threats, may have shaped differences among states' maritime strategy. The emerging non-traditional threats such narcotic trafficking, terrorism and human smuggling, have contributed to the threats for many states, this further justifies the importance of maritime strategy.
\end{abstract}

\section{Keywords:}

maritime strategy; maritime states; national interest; survival; threats

\section{Introduction}

International relations is not only a study about theory but more importantly it is a study about security (Nor Azizan \& Zarina, 2009). Throughout the Cold War period, security studies focused on military threats such as war and conflicts, and weapons competitions between the two power blocs --one led by the United States and another by the Soviet Union. However, with the end of the Cold War-marked by the fall of the Berlin Wall--scholars have given more attention to non-traditional or non-military security issues (Zarina, Nasuha, \& Halim, 2013). These include issues such as terrorism, narcotic trafficking, and human smuggling. Likewise in 1989, the discussion about national security has also increasingly focused on maritime security (Corbett, 1911; Mahan, 1889; Till, 1984). Maritime terrorism, illegal fishing, smuggling and trafficking of people and goods, refugees and other cross maritime border issues, have attracted scholars to analyse them. To understand maritime security, it is necessary to discuss maritime strategy. Therefore, maritime strategy is "the comprehensive direction of all aspects of national power to achieve specific policy goals in a specific situation by exercising some degree of control at sea" (Hattendorf, 2013, p. 10). This is due to the changing international politics such as the emerging non-traditional maritime security issues, which advises that 
a maritime strategy for Indonesia is needed (Buddy, Zarina, \& Farizal, 2018).

Like the concept of national security, maritime strategy varies from one country to another; there is no "one size fits all". The study of maritime strategy by scholars as evidenced by the seminal works of Mahan (1889), Hattendorf (2004), Bruns (2014), and Rubel (2015) from the US, goes as far back as 1898. Maritime strategy is crucial for many, including for Continental States. Mahan (1889), a naval historian, was known as the first theorist to systematically point out the strategic importance of naval operations to warfare. Notably, Mahan laid the foundations for a theory of naval strategy through his comprehensive descriptions of the histories of modern naval warfare. In addition, some important points about Mahan's concept are presented by Gough (1988), Hattendorf (1989), Klein (2004), Till (2005), William (2008), Vego (2009). Klein (2004) for example, suggested that Mahan's prime contribution lies in the important links he established between maritime and naval activities to national and international issues, besides laying the foundations for developing naval strategy. Mahan examined national policy, sea power, sea control, offensive versus defensive operations, speed and mobility, communications, trade, concentration of force, and strategic position (Klein, 2004). While there is a national policy yet there is no national security policy on maritime strategy.

There are three main conditions that determine the strategic value of any states (Mahan as cited in Vego, 2009). This includes the offensive or defensive military strength of the place, the resources of the place itself and the resources of the surrounding state. Although Mahan suggested that the main requirement of naval supreme power was the strength of heavy warships, there is a need to consider "... training, morale, the effectiveness of command, tactical disposition (in particular, the skill of pitting all of your force against a portion of the opponent's)" besides an aggressive winning tactic to destroy the opponent (Till, 2005, p. 35).

In fact, sophisticated warfare technology (submarine communications, cruiser warfare, mines, sub-marines, torpedoes) was a secondary factor, which means decisive naval battles are a key factor in maritime strategy (Mahan as cited in Gough, 1988). Besides the military aspects in naval battle, Mahan advocated the expansion of other areas to broaden the nation's maritime strategy, especially during peaceful times. Moreover, commercial sea routes are better controlled via a mobile naval fleet which has strategic local ports used as the naval operations base (Hattendorf, 1989). The key guidelines developed by Mahan are as follows; the true objectives of the navy in times of war and peace; building supportive logistics bases; effective communications between these depots and the home base; the military value of commerce-destroying as a decisive or secondary operation of the war; the system upon which commerce-destroying can be most efficiently conducted, whether by scattered cruisers or by holding in force some vital center through which commercial shipping must pass (Mahan as cited in Benner, 2004). In addition, it was vital to acquire international colonies, naval bases and coaling stations to support both military and commercial maritime operations (Mahan as cited in Williams, 2008).

However, there were weaknesses in the Mahan concept, specifically about his failure to appreciate the importance of convoys in a prolonged war and the deep impact of submarines, torpedoes and mines in a future naval war (Gough, 1988). He also highlighted the fallacies of Mahan's concept, such as his belief that the nation needed a concentrated battle fleet, and that the Naval forcescould protect the people and sea commerce in difficult times.

Another important contribution, came from Turner (2001) who introduces the new term "Sea Control" which was intended to compare more realistic controls in restricted 
areas and for limited periods of time. It is very difficult to maintain the security of the area in the airspace, under the sea and at surface sea today especially in terms of maintaining strength overseas. Besides, Turner also explained the methods of weapon systems in Sea control.

The complicated nature of maritime strategy was discussed by Hattendorf (2013). Notably, the navy constitutes only one component of the strategy, which should incorporate diplomacy, merchant trade and sea defence, fishing, safeguarding, conserving and defending the exclusive economic zone at sea, coastal defence, national borders' defence, and offshore islands security (Hattendorf, 2013). In essence, maritime strategy involves participation in regional and worldwide issues relating to the use of oceans, the skies over the oceans and the land under the seas besides influencing and controlling developments on land (Morrison, 2011; Scott, 2004).

In general, strategic maritime studies can be divided into two sections. On one hand, the discussion has focused on maritime strategy, and on the other hand, it has emphasized the appropriate concepts and factors affecting the strategy. Among pioneer scholars in the field of maritime strategy were Mahan (1889), Corbett (1911), Booth (1977), Grove (1990), Turner (2001), and Till (2005) who have all made major contributions to the field.

It is the purpose of this article to discuss the evolution and development of maritime strategies focusing on the Asia Pacific region. In particular, the discussion seeks to investigate why states adopt maritime strategy and how to implement the strategies. Although countries perceive national security to be important, yet they have not all focused on maritime strategy. Because developing naval power is too expensive, due to the vast area to protect, and government policy seems to be more land-based. The article will first discuss the development of maritime strategies for continental states including the US, and India. Next, the article will analyse the strategies from maritime states including United Kingdom, Australia, Japan, and Singapore as well as Indonesia, one of the largest maritime nations and an important founding member of ASEAN, a regional institution in Southeast Asia (Sugiarto et al., 2017). By doing so, it is hoped that the discussion will help maritime countries such as Indonesia in formulating its comprehensive maritime strategy.

\section{Methods}

Most of the data for this article is obtained from secondary sources that are publicly accessible which includes official documents from Indonesia, the United Kingdom, the United States, and Australia. Academic books and journals on maritime issues, maritime strategies, national security, and reputable sources from open access journals, have also been consulted. For the purpose of this research, this data collected was analyzed using Atlas.ti software through coding manuals for qualitative research.

\section{Results and Discussion}

Maritime Strategy in Continental States: US and India

As a superpower, US maritime strategy development has undergone several changes in accordance with global trends caused by changing political events and technological developments. The changes can be seen beginning from Ford's 1971 presidency that developed the concept of the mission of the navy, Reagan's 1981 Maritime strategy, Bush's 1989 administration and From the Sea concept, Clinton's 1994 forward thinking concept of the sea and to Bush's 2002 Sea power 21 concept (Swartz, 2005). The view that maritime strength does not concern conquering territories but also looks at controlling coastlines and smaller waterways is also supported by Menon who pays attention to amphibious operations in history, speed in battle, and the synergy between 
technology and strategy (Menon, 1998). Next, Wiley (2016) who observed that the debate over maritime strategy in the 1980s stemmed from the United States and its allies' response to Soviet aggression in Central Europe during the cold war era on a bipolar world where the competition between communist and capitalist was at its height. This involved carrier raids and amphibious assaults against Soviet in the Black, Mediterranean, Norwegian Seas, and the Pacific, and the strategy was criticized as it appeared to be a rationalization for the 600 ships involved rather than a serious wartime plan. This strategy was seen as unreasonable, as once the Soviet military threat subsided, the rationale for building the fleet was lost and the new administration decided to reduce its size, without a corresponding reduction of the nation's overseas obligations.

Wiley (2016) suggested that the navy and marine corps of the Cold War era in the 1970s were gradually transformed and embraced a more cooperative, sea power strategy for the $21^{\text {st }}$ century. This transformation was also shaped by the historical experiences of the 1990s and 2000s. Then, Hoyt (2007) observed the need for maritime strategy to extend control to the nation's economic interests and guarding it against threats from other states. Additionally, Ho (2008) looked at the broader focus to prevent conflict, counter terrorism and provide humanitarian assistance. This shift from a narrow focus on winning wars emphasizes cooperation between nations. An important contribution was from Taylor (2008) who assessed the need for routine and effective cooperation between regional and international maritime nations to secure a free and safe maritime domain. Quite understandably, it calls for an integrative and robust global maritime alliance that is based on trust, and thus, enables greater prevention and security. This approach emphasizes the important role of governmental and nongovernmental, public and private maritime partners.
Additionally, Kraska (2012) cited the Chairman of the Joint Chiefs of Staff Admiral, Michael G. Mullen, who claimed that sea control belonged to old schools of thought whereas the newer maritime strategy recognizes that the economic strength of nations increase when the seas are made safe and free for all. Another study, by Bruns (2014), analyses U.S. Navy Strategy \& American Sea Power from "The Maritime Strategy" (1982-1986) to "A Cooperative Strategy for 21st Century Seapower" (2007). He pointed out the intricate links between strategy, planning, and force structure, considering theories, sea power, the political and military uses of the sea, the links between different levels of strategy, naval missions, and some particulars of the maritime domain that guide formulation of naval and maritime strategy (Wiley, 2016).

Subsequently, in 2015, the US revised the 2007 maritime strategy with the title "A Cooperative Strategy for 21st Century Seapower" (U.S. Navy, 2015). This was made with respect to the vastness of the maritime region that required naval forces to protect and maintain not only the economic and security interests of the U.S, but also the stability of the Indo-Asia-Pacific region. Cropsey \& McGrath (2018) observed that in order to formulate global strategy, it requires an extensive government plan involving military, diplomatic, geo-strategic, industrial workforce, and budgetary implications, amongst others. Thus, the elements of America's maritime strategy includes diplomacy, economics, global, sea control, maritime security, navy strength, marine power, maritime cooperation, joint concepts, maritime domains, military values, politics, and choke point (a narrow strait that is strategic for sea shipping lines).

Scholars from India such as Menon (1998) emphasized that such tactics are necessary as there was a shift from just controlling territories towards comprehensive security measures involving coastlines and smaller 
waterways. Dhowan (2015) documented the next phase of India's maritime security strategy in his masterpiece, Ensuring Secure Seas: Indian Maritime Security Strategy that discussed various strategic options. These include deterrence and conflict strategies, coastal and offshore security strategies, maritime force and capability development strategies and strategies for shaping a favorable and positive maritime environment. Dhowan (2015) had earlier documented the maritime strategy of India and identified various strategic points of the sea such as the Suez canal, Strait of Hormuz, Straits of Malacca, Singapore Strait, Sunda Strait, Lombok Strait, the Ombai Straits. He suggested that international sea-lanes become one of the considerations in determining its strategy. Meanwhile, Chandramohan (2016) conducted a major study of India's maritime strategy improvement in the Asia-Pacific region.

Maritime Strategy in Maritime States: UK, Australia, Japan, Singapore, and Indonesia

For maritime countries, studies in this area include the works of scholars from the UK such as Corbett (1911), Ken Booth (1977), James Cable (1983), John Richard Hill (2000), Geoffrey Till $(2005 ; 2006)$. Although the UK is not an Asia Pacific country, yet its maritime strategy is the best and the earliest in the world. Studying UK's maritime strategy is useful in terms of the lessons learned for Asia including Indonesia.

Corbett (1911) defined sea command as "the control of maritime communications for commercial or military purposes", and that maritime strategy is determined by an action plan of war that combines the strategies of the army and navy. He stressed that naval strength cannot be achieved by itself but it constitutes part of maritime strategy, and that a successful wartime maritime strategy involves the intricate connections between land, sea and air strengths. Maritime Strategy was never seen as relying on communications, but Corbett (1911) argued otherwise, attributing the problems of
Naval Strategy to passage and communication. According to Corbett, the maintenance of Communications constituted the essence of naval influence. Where states are closely related to sea warfare and their perfection comes from sea command and control. This was augmented by Gough (1988) who suggested that keeping the lines of operation and communication open leads to better strategic functioning of the navy. Gough (1988) explains Corbett's grand and minor strategy, the former relating to purpose, economic functions and international relations and the latter relating to warfare details such as planning army, navy or combined operations. It required being on the offensive in acquiring and influencing the nation's maritime objectives as well as being on the defensive, that is to deny the enemy's objective.

Corbett's starting point in developing naval strategy draws upon Mahan's notion of command of the sea but includes more than the massive and decisive confrontation of naval forces. As put by forward Williams (2008), the objective must always be directly or indirectly either to secure the command of the sea or to prevent the enemy from securing it. Williams (2008) also distinguished between Corbett, who acknowledged the importance of naval operations and Mahan, who believed that naval power was a greater influence than land armies. Considering that humans' natural habitat is on land and not the sea, nations at war always based decisions on what the army can do against the enemy's territory and maintaining control over the country's land.

In connection with maritime strategy, Booth (1977) looked more specifically at the role of navy. Booth argued that the function of navies in the modern age includes their Policing role (Coastguard responsibilities, Nationbuilding), Diplomatic Role (Negotiation from strength, Manipulation, Prestige), Military Role (balance of power, Power Projection). While, Till (1984) described maritime strategy as comprising two essential parts. First, sea 
battles that include decisive battles, fleet in being (standby fleet), blockade, and second, the preventive sea measures such as coastal protection, protection of trade, projection of power ashore, naval diplomacy and strategic deterrence. He synthesized the works of various authors (Bateman \& Sherwood, 1992). Till observed the relativeness of sea power which most countries possess. The degree of sea power in each country depends on the following factors and its combination; their naval strength, shipbuilding expertise, skills in marine sea power insurance, or their capacity to supply seafarers. Furthermore, Till (2005) summed up Baer's (1994) views that to achieve sea power, a nation has to internally agree on the value of an aggressive big fleet triphibious Navy, as outlined by Mahan's principles, besides having public and professional support.

In reviewing Corbett's work (1911) that advocated an army that works with the navy to conquer overseas territories and to outflank land-bound adversaries with amphibious operations, (as cited in Till, 2006) noted that this strategy focuses on confusing rival plans and making one's own and the allies' positions stronger. In addition, Till (2009) suggested that the typical problems for navies and coastguards include defence inflation, budget limitations, resources - commitments gap, sea blindness, and land-centric culture. These are the limitations for the navy expansion.

The modern concept of 'sea control', is defined by the Royal Navy as the exclusive freedom and power to exploit the use of part of the sea and also, if need be, make it inaccessible to rivals. However, besides sea denial, other weak naval strategies involve attacking merchant ships and coastal hit and run raids. Speller (2005) observed the acknowledgement given by the authors of British Maritime Doctrine (BR1806) to the established concepts of maritime strategy that include access, mobility, versatility, sustained reach, resilience, lift capacity, poise, and leverage.
According to Grove (2006) who examined various Royal Navy documents such as the 2001, 'The Future Navy' and 'and 'Future Navy Operational Concept', stressed four core capabilities for future fleets, i.e. power projection, flexible global reach, optimized access for the joint forces via sea control and theatre entry. Wide-ranging aspects of maritime security are also highlighted such as Command, Control, Communications, Computers, Intelligence, Surveillance and Reconnaissance (C4ISR). In Heuser's (2010) assessment of Till's work, he highlighted Till's prediction of paradigm shifts in the Western navies post-Cold War (Till, 1994). He envisaged that instead of securing sea control and protection against raids, there would be a focus on coastal strategies and protection, or "littoral warfare". This however constitutes one of the many shifts in maritime warfare.

The British Maritime Doctrine BR 1806 outlined the important role of navies in the postCold War era. Apart from providing required protection and surveillance, their diplomatic influence and cooperation in strategic alliances is a very fundamental aspect in the fastchanging regional and international maritime domains (Till, 2005). Mière (2013) observed the evolving nature of the strategy, while Cable (1983) believed that the strength of British navies depended on their ability to predict as well as the adaptability and plausibility of their strategy in relation to present and future policies. Generally, though, the aim of British maritime strategy was a combination of the financial support of Continental allies and the exertion of maritime pressure through blockade, the threat of amphibious landings, attacks and raids on threatened coastlines and through the seizure of their adversaries' farflung colonies and bases (Gardner, 2006).

Additionally, Till also forecasted the modern navy tasks in the future that correspond with a reduction in resources. Politically, naval planners will also receive less strategic guidance as compared to during the Cold War 
era (Till, 2008). This, however, is a reflection of the past when British Chiefs complained of getting little guidance from their political masters, a time that is often seen as a forecast and preparation of things to come in the future (Grove, 2006). Another major contribution comes from Hill (2000) who described the tools used by the Medium Powers as 'levels of conflict' that required understanding the levels of command, tasks and management of military forces instead of the nature of conflict. This concept is also described in the "The Joint Doctrine Publication 0-10 British Maritime Doctrine" which specifies that the hierarchy levels span all warfare areas [tactical, operational and strategic] (Britain MoD, 2011).

Being a maritime state, the UK government issued official maritime security strategy documents in 2014 certified by four departments, i.e. the Secretary of foreign affairs and commonwealth, Secretary of State, Secretary of Defense Affairs, and Secretary of State for Transport. The main purpose of the UK maritime security strategy is as follows:

"To promote a secure international maritime domain and uphold international maritime norms; to develop the maritime governance capacity and capabilities of states in areas of strategic maritime importance; to protect the UK and the overseas territories, their citizens and economies by supporting the safety and security of ports and offshore installations and Red Ensign Group (REG)-flagged passenger and cargo ships; to assure the security of vital maritime trade and energy transportation routes within the UK marine zone, regionally and internationally; to protect the resources and population of the UK and the overseas territories from illegal and dangerous activity, including serious organised crime and terrorism" (British Government, 2014, pp. 10-11).
The strategy is two-fold; one concerns developing national capabilities utilizing available resources and the other focusing on international cooperation between governments to identify, assess and address maritime security issues locally and internationally. In order to remain relevant, the strategy should also be continuously examined and improved.

On the other part of the continent is Australia, an importance US ally. Specifically, in strategy, theories of sea power and maritime strategy are to be used in warfare and also in peaceful times. Secondly, complex principles are used during war times and thirdly, that joint approaches are used, acknowledging the importance of both land and air tactics. Lastly, the maritime strategy also includes civil components of maritime power (the marine industries and maritime infrastructure). Essentially, they described the Australian maritime strategy as one that optimizes the country's scarce resources to defend and protect Australia's maritime assets against any maritime attacks and to uphold a safe and secure environment (Bateman \& Sherwood, 1992).

Meanwhile, Donohue (2000) has listed the importance of geography. Considering Australia's geographical location in a region with the busiest shipping lanes in the world, he highlighted how Australia's active role is instrumental in influencing regional maritime cooperation on all levels of defence and industry whilst creating and maintaining communications with its neighbors. The Indonesian maritime project will impact Australia and the rest of the Indo-Pacific region especially by providing powerful insights about the challenges faced in building maritime power (Till, 2015, p. 9). Scott (2004) also stated that with the advances made in technology, it was crucial that air, sea and land forces work together, besides integrating the traditional blue water maritime concepts of sea denial and sea control. 
The Australian Maritime Doctrine (2000) was an Australian spin-off of British formulated concepts and reflected the nation's national interests. In writing about the need for nations, Till (2005) suggested that Australia should retain a greater focus on sea control, and that this strategy, together with air control, will enable greater influence on land. He stressed that the preconditions for sea control should not be taken for granted.

Similarly, McCaffrie (2006) outlined the requisites of a maritime strategy as the combination of all aspects of national power, not excluding the military, economic and diplomatic aspects that are deployed for national security. The specific requisites for an Australian maritime strategy includes "mobility in mass, readiness, access, flexibility and adaptability, reach, poise and persistence, maneuver" (McCaffrie, 2006). Notably, in a speech to the Royal Australian Navy (RAN) Maritime Conference, Morrison (2011) stressed that to ensure the future relevance of maritime strategy, it must involve the army or air force and that this strategic alliance defines maritime strategy. Maritime strategy is therefore, a triphibious exercise, and is not exclusive to the naval forces. However, Till (2013) added that budget constraints may limit the use of maritime concepts and for maritime strategy to be fully implemented, Australia needed to defend navigation freedom, to actively pursue measures that reduce the risks of accidental encounters at sea and to develop wider naval relationship networks of mutual benefit around the region.

In examining the security threats at sea, Percy (2013) identified four security risks, i.e. piracy; people smuggling (both illegal migration and human trafficking); illegal, unreported and unauthorized (IUU) fishing; and narcotics smuggling. By focusing on narcotics smuggling, which is considered one of the longest criminal maritime security threats, he also discussed different types of control and whether these maritime threats can be resolved by traditional maritime strategy. Furthermore, Kainikara (2013) not only agreed with the view that air strategy is essential to Sea control, but also that success of sea control is relative to the ability of the air force to control the air. For maritime strategy to be successful, therefore, it requires strong support from air strategy.

The next topic for discussion is the development of maritime strategies in Japan, and Singapore. According to Kaneda (2002) the development of maritime strategy in Japan, faced threats from North Korean missiles and spy ships in the form of "Taepodong", during the post-Cold War era. This led to Japan's "maritime coalition" strategy that involved building an integrated, anti-ballistic missile system, using information systems. Research on Singapore's Maritime Strategy focused on the Straits of Malacca and the need to maintain international co-operation and develop a balanced military strength with respect to other nations (Rotte, 2002).

Indonesia is an important state in the region. Its free trade island city, Batam, has contributed wealth to Indonesia (Adiwan, 2017). Specific studies on Indonesian maritime strategy are limited. Indonesian scholars include Mangindaan (2002) whose article Maritime Strategy Indonesia in 2000-2010, argued that due to the financial difficulties facing Indonesia in safeguarding national interests in maritime territory, it is strongly recommended and necessary to cooperate with other forces such as official political-diplomatic power and cooperation among departments. Keliat (2009) examined two areas of Indonesian maritime strategy; i.e. the concept of maritime safety and its implications for Indonesia. Other similar research studies include one by Melda (2009) who described the Indonesian view of maritime security in South East Asia, as well as Forward (2009) who worked on "the Indonesian submission to determine the validity of the IMO's declaration at international law". 
The researcher Djalal (2013) examined the responsibilities and capabilities of the country with regard to its diverse land, air, sea and seabed boundaries. This study was undertaken in light of the widening territories of the Unitary State of the Republic of Indonesia as a result of the worldwide acceptance of UNCLOS 1982. To this end, Sebastian, Supriyanto, \& Arsana (2014) observed the need for Indonesia to take measures in re-strategizing its diplomatic, legal, and security initiatives to face potential external maritime challenges. On the other hand, Indonesian maritime policies against illegal foreign fishing in Indonesian waters, has jeopardized the ambitions of China's Maritime Silk Road Initiative and Indonesia's Global Maritime Fulcrum. It has also economically hurt China's fishing industry (Hongzhou, 2015). In addition, with the appearance of non-traditional maritime security problems, Indonesia should reformulate its maritime strategy (Buddy, Zarina, \& Farizal, 2018).

Furthermore, the national maritime strategy of other countries and the establishment of Indonesia's national maritime strategy will support the role of naval diplomacy in the future (Marsetio, 2014). Salim (2015) also explained that since 2005, the Indonesian Navy has formulated the Nusantara Marine Defense System and continued with the formulation of the Indonesian Maritime Defense System. However, this concept is not fully supported with higher level commitment, so it cannot be used as a reference in carrying out maritime defense. Additionally, Setianegara's (2014) writing about maritime strategy on Nusantara naval and the world maritime axis, considered several factors including maritime history, environmental geopolitical order, maritime trade and energy security, maritime control, strategy on time of peace and conflict time, and strength development strategy. Others like Suropati, Sulaiman \& Montratama (2016) suggested the need for Indonesia to study strategic forward defense (SFD) to face external threats in the navy and air force sectors. This concurs with the concept of a blue water navy as practiced by the US and UK.

Hattendorf (1989) stated that although Britain and the United States held different positions in late 19th and in the 20th century, they saw a common need to take on a leadership role in controlling the basic network of bases and fleets around the world. This change was necessary to maintain a balance of power, especially against other land-based rivals. This view was strongly validated by Gough (1988) who maintained the relevance of principles founded by the two classical theorists, Alfred Thayer Mahan and Sir Julian Stafford Corbett. Essentially, he outlined three considerations resulting from their work; firstly, the vital economic and political aspect of sea security. Second, the need for big and small nations to take sea power seriously, and third, the rich naval lessons to be learnt from historian-strategists that need to be digested and well understood. Till (2005) also strongly advocated the application of the Mahanian and Corbettian theories, acknowledging the fact that they needed to be used in the specific contexts of the national security strategies of each country. He concluded, however, that the basic concepts of maritime strategy are universally and generally applicable (Till, 2005).

Gardner, Roskill and Gretton (2006) concluded that the traditional principles of maritime strategy were not required to make huge changes because of new technology. Brittania's role as a world police force meant that they were successful in halting the slave trade and in diminishing pirates (Gough, 1988). However, as a result of the shifts in Western Europe's balance of power, its role was also increasingly supplemented by the naval strength of Germany, Japan and the United States. As Brittania's rule over the seas since 1815 was coming to an end, the focus became who would replace Brittania's lead as well as how the direction of international affairs would be configured in the future. 
From discussions about the development of maritime strategies by the American, British, Australian, Japanese, Indian, Singapore and Indonesian governments, the similarities and differences in elements of maritime strategy between maritime countries and continental countries are displayed in Table 1.

From the Table 1 it can be seen that the different elements of maritime strategy in maritime countries compared to continental countries are access, adaptive, balance, conserving and defending the exclusive economic, defence, deterrence, fishing, influence, maneuver, maritime coalition, maritime development, maritime environment, national borders' defence, naval strength, power projection, sea denial, sea dependency, technological expertise, and the methods of weapon systems in sea control.

Furthermore, from the discussion, the elements of maritime strategy in each country have similarities and differences. This can be seen in Table 2.

From Table 2, the elements of Indonesia's maritime strategy are based on suggestions from earlier research recommendations that Indonesia's maritime strategy should have elements of diplomacy, economy, sea control, maritime security, joint concepts, war and peace time, trade, forward defense, politics, and maritime history. Therefore, Indonesia needs to formulate a maritime strategy, which is in line with national interests and strategic environmental situations and by considering strategy concepts from experts or other countries that already have maritime strategies.

\section{Conclusion}

As one of the countries in the Asia Pacific, Indonesia is considered a maritime country, yet it can learn key elements for shaping its maritime strategies from continental countries such as the United States, and India, namely threats, diplomacy, economics, geography, global, sea control, maritime security, navy strength, sea
Table 1.

Elements of Maritime Strategies in Continental States vs. Maritime States

\begin{tabular}{|c|c|c|}
\hline No & $\begin{array}{l}\text { Maritime States } \\
\text { (UK, Australia, } \\
\text { Japan, Singapore, } \\
\text { and Indonesia) }\end{array}$ & $\begin{array}{c}\text { Continental States (US and } \\
\text { India) }\end{array}$ \\
\hline
\end{tabular}

1. Access

2. Adaptive

3. Balance

4. Choke Point

Choke Point

5. Coastal Defence Coastal Defence

6. Command at Sea Command at Sea

7. Communication Communication

8. Cooperation Cooperation

9. -

Conserving and Defending The Exclusive Economic Zone at Sea

10. Defence -

11. Deterrence -

12. Diplomacy Diplomacy

13. Economy Economy

14. - Fishing

15. Global Global

16. Influence -

17. Joint Joint

18. Maneuver -

19. Maritime Coali- tion

20. Maritime Devel- opment

21. Maritime Domain Maritime Domain

22. Maritime Envi- ronment

23. Military Value Military Value

24. Mobility Mobility

25. Naval Base Naval Base

26. - National Borders' Defence

27. - Naval Strength

28. Politic Politic

29. Power Projection -

30. Sea Control Sea Control

31. Sea Denial -

32. Sea Power Sea Power

33. Security Security

34. Sea Dependency -

35. Technological Expertise

36. Threat Threat

37. Trade Trade

38. - The Methods of Weapon Systems in Sea Control

39. War and Peace War and Peace Situation Situation 
Table 2.

Strategy Elements According to Selected Countries

\begin{tabular}{|c|c|c|c|c|c|c|c|c|}
\hline No & Element & U.S. & India & UK. & Australia & Japan & Singapore & Indonesia \\
\hline 1 & Adaptive & - & - & $\checkmark$ & - & - & - & - \\
\hline 2 & Access & - & - & $\checkmark$ & $\checkmark$ & - & - & - \\
\hline 3 & Threat & $\checkmark$ & - & $\checkmark$ & $\checkmark$ & - & - & $\checkmark$ \\
\hline 4 & Diplomacy & $\checkmark$ & - & $\checkmark$ & $\checkmark$ & - & - & $\checkmark$ \\
\hline 5 & Economy & $\checkmark$ & - & - & $\checkmark$ & - & - & - \\
\hline 6 & Geography & - & - & - & $\checkmark$ & - & - & - \\
\hline 7 & Global & $\checkmark$ & - & $\checkmark$ & - & - & - & - \\
\hline 8 & Sea Control & $\checkmark$ & - & $\checkmark$ & $\checkmark$ & - & - & $\checkmark$ \\
\hline 9 & Maritime Security & $\checkmark$ & $\checkmark$ & $\checkmark$ & - & - & & $\checkmark$ \\
\hline 10 & Navy strength & $\checkmark$ & - & - & - & - & - & - \\
\hline 11 & Sea Power & $\checkmark$ & - & $\checkmark$ & $\checkmark$ & - & - & - \\
\hline 12 & Maritime Cooperation & $\checkmark$ & - & $\checkmark$ & $\checkmark$ & - & $\checkmark$ & - \\
\hline 13 & Balance & - & - & - & $\checkmark$ & - & $\checkmark$ & - \\
\hline 14 & Maritime Coalition & - & - & - & - & $\checkmark$ & - & - \\
\hline 15 & Communication & - & - & - & $\checkmark$ & - & - & - \\
\hline 16 & Joint Concepts & $\checkmark$ & - & $\checkmark$ & $\checkmark$ & - & - & $\checkmark$ \\
\hline 17 & Maneuver & - & - & - & - & - & - & - \\
\hline 18 & Maritime Domain & $\checkmark$ & - & $\checkmark$ & $\checkmark$ & - & - & - \\
\hline 19 & War and Peace Time & - & - & - & $\checkmark$ & - & - & $\checkmark$ \\
\hline 20 & Method in Sea Control & - & - & - & - & - & - & - \\
\hline 21 & Mobility & - & - & $\checkmark$ & $\checkmark$ & - & - & - \\
\hline 22 & Value of Military & $\checkmark$ & - & $\checkmark$ & $\checkmark$ & - & - & - \\
\hline 23 & Naval Base & - & - & $\checkmark$ & - & - & - & - \\
\hline 24 & Deterrence & - & $\checkmark$ & - & - & - & & - \\
\hline 25 & Influence & - & - & - & - & - & - & - \\
\hline 26 & Sea denial & - & - & $\checkmark$ & $\checkmark$ & - & - & - \\
\hline 27 & Trade & - & - & $\checkmark$ & - & - & - & $\checkmark$ \\
\hline 28 & Fishery & - & - & - & - & - & - & - \\
\hline 29 & Command at sea & - & - & $\checkmark$ & - & - & - & - \\
\hline 30 & Sea Boundary Defense & - & - & & - & - & - & - \\
\hline 31 & Forward Defence & - & - & - & - & - & - & $\checkmark$ \\
\hline 32 & Coastal Defence & - & $\checkmark$ & $\checkmark$ & - & - & - & - \\
\hline 33 & Politic & $\checkmark$ & - & - & - & - & - & $\checkmark$ \\
\hline 34 & Power Projection & - & - & $\checkmark$ & - & - & - & - \\
\hline 35 & Maritime History & - & - & - & - & - & - & $\checkmark$ \\
\hline 36 & Choke point & $\checkmark$ & $\checkmark$ & - & - & - & $\checkmark$ & - \\
\hline
\end{tabular}

Note:

$\checkmark$ : available

- : not available

Source: Complied by Authors

power, maritime cooperation, joint concepts, maritime domain, value of military, deterrence, coastal defence politics, and choke point. Furthermore, Indonesia also can learn from maritime states such as UK, Australia, Japan, and Singapore about several key elements on maritime strategy particularly, adaptive, access, balance, maritime coalition, communication, war and peacetime, mobility, naval base, sea denial, trade, command at sea, and power projection. In addition, the thoughts of scholars such as Mahan, Corbett, Hattendorf, Turner, Ken Booth, 
and Till, other elements of maritime strategy can be implemented by Indonesia including geography, policing, maneuver, methods in sea control, influence, fishery, technological expertise and sea boundary defense.

\section{References}

Adiwan, F. A. (2017). Special economic zone at the crossroads: The case of Batam. Jurnal Ilmu Sosial dan Ilmu Politik, 21(2), 132-146. doi: 10.22146/jsp.30438

Bateman, W., \& Sherwood, R. (1992). Principles of Australian maritime operations (No. 265). Canberra. Retrieved from http:// www.navy.gov.au/sites/default/files/ documents/Principle_of_Aust_Maritime_ Operations_265_opt.pdf

Baer, G. W. (1994) One hundred years of sea power: The US Navy, 1890-1990. Stanford: Stanford University Press.

Benner, S. M. (2004). Evolution of maritime strategy...is sea power 21 the answer? Carlisle: Pennsylvania.

Booth, K. (1977). Navies and foreign policy. London: Croom Helm.

Britain MoD. (2011). Joint doctrine publication 0-10 British maritime doctrine. Swindon. Ministry of Defence. Retrieved from www.mod.uk/dcdc

British Government. (2014). The UK national strategy for maritime security. London: Williams Lea Group. Retrieved from www.gov.uk/government/publications

Bruns, S. (2014). U.S. Navy strategy \& American sea power from "The Maritime Strategy" (1982-1986) to "A Cooperative Strategy for 21st Century Seapower" (2007). Kiel: Kiel University.

Buddy, S., Zarina, O., \& Farizal, M. R. (2018). The Need to reform Indonesia's maritime strategy: A Review. Indonesian Journal of Geography, 50(2), 145-153. doi: 10.22146/ ijg.27954

Cable, J. (1983). Britain's naval future (First). London: The Macmillan Press Ltd.
Chandramohan, B. (2016). India's evolving maritime security strategy and force posture. Future Directions International, 2015, 2-8. Retrieved from http://www. futuredirections.org.au/wp-content/ uploads/2016/03/India's-EvolvingMaritime-Security-Strategy-and-ForcePosture.pdf

Corbett, J. S. (1911). Some principles of maritime strategy. London: Project Gutenberg.

Cropsey, S., \& Mcgrath, B. (2018). Maritime strategy in a New Era of Great Power competition. Washington D.C.: Hudson Institute.

Dhowan, R. (2015). Ensuring secure seas: Indian maritime security strategy. (J. S. S. Sanjay J Singh, NM, Sarabjeet S Parmar, Ed.). New Delhi: Integrated headquarters, Ministry of Defence (Navy). Retrieved from http://indiannavy.nic.in/sites/ default/files/Indian_Maritime_ Security_Strategy_Document_25Jan16. pdf

Djalal, H. (2013). Pengelolaan batas maritim dan kawasan perbatasan: Menentukan batas negara guna meningkatkan pengawasan, penegakan hukum dan kedaulatan NKRI. Jurnal Pertahanan, 3(3), 17-39.

Donohue, H. (2000). The oceans and Australia's defence. In D. Wilson \& D. Sherwood (Eds.), Oceans Governance and Maritime Strategy (p. 246). Sydney: Allen \& Unwin. Forward, C. (2009). Archipelagic Sea-Lanes in Indonesia - Their Legality In International. Australian \& New Zealand Maritime Law Journal, 23(2), 143-156.

Gardner, J. (2006). British naval thinking and technology in the Second World War. In G. Till (Ed.), The Development of British Naval Thinking, 214. New York: Routledge Taylor \& Francis Group. doi: 10.4324/9780203485620

Gough, B.M.(1988). Maritimestrategy: Thelegacies of Mahan and Corbett as philosophers of sea power. RUSI Journal, 133(4), 55-62. doi: 10.1080/03071848808445330 
Grove, E. (1990). The future of sea power. London: Routledge.

Grove, E. (2006). The discovery of doctrine British naval thinking at the close of the twentieth century. In G. Till (Ed.), The Development of British Naval Thinking (pp. 182-191). New York: Taylor and Francis.

Hattendorf, J. B. (1989). Maritime strategy and the balance of power: Britain and America in the twentieth Century. In J. B. Jordan, B. Hattendorf, \& O'Neil Robert (Eds.), Maritime strategy and the balance of power britain and america in the twentieth century (p. 373). New York: Palgrave Macmillan. Hattendorf, J. B. (2013). What is a maritime strategy? (No.1). Soundings. Canberra. Retrieved from http://www.navy.gov.au/sites/default/files/ documents/Soundings 1 - Hattendorf What is a Maritime Strategy.pdf

Hattendorf, J. B., Phil, D. (2004). The evolution of the U.S. Navy's maritime strategy, 1977-1986. Newport, Rhode Island: Naval War College.

Heuser, B., \& Cambridge University Press. (2010). The evolution of strategy: Thinking war from antiquity to the present. New York: Cambridge University Press.

Hill, R. (2000). Medium power strategy revisited. In Sea Power Centre-Australia Working Paper.

Ho, J. (2008). The U.S. maritime strategy: A cooperative strategy for 21 st Century Seapower. RSIS Commentaries. Singapore: RSIS. Retrieved from https://www.rsis. edu.sg/wp-content/uploads/2014/07/ CO08081.pdf

Hongzhou, B. Z. (2015). Indonesia's war on illegal fishing: Impact on China. RSIS Commentaries, (192), 2013-2015. Retrieved from https://www.files.ethz.ch/ isn/194173/CO15192.pdf

Hoyt, T. D. (2007). The United States and maritime strategy: A parochial view from the U.S. Naval War College. Elsevier, 51(4), 577-584. doi: 10.1016/j. orbis.2007.08.003
Kainikara, S. (2013). Air force in a maritime strategy: Challenges and opportunities. In J. Jones (Ed.), A maritime school of strategic thought for Australia: perspectives (pp. 107-111). Sea Power Centre - Australia. doi: 10.1080/19480881.2014.882116

Kaneda, H. (2002). Japan's maritime strategy in the new era. In J. Schwarz, W. A. Herrmann, \& H.-F. Seller (Eds.), Maritime strategies in Asia (pp. 241-263). Bangkok: White Lotus Press.

Keliat, M. (2009). Keamanan maritim dan implikasi kebijakannya bagi Indonesia. Jurnal Ilmu Sosial dan Ilmu Politik, 13(1), 19. doi: 10.22146/jsp.10970

Klein, J. J. (2004). Corbett in orbit: A Maritime Model for strategic space theory. Naval War College Review, (1), 60-74.

Kraska, J. (2012). America's maritime challenges and priorities The Asian dimension. In J. H. Ho \& S. Bateman (Eds.), Maritime challenges and priorities in Asia (p. 320). New York: Routledge Taylor \& Francis Group. doi: 10.4324/9780203116272

Mahan, A. T. (1889). The Influence of Sea Power Upon History 1660-1783. Boston: Little Brown and Company.

Mangindaan, R. (2002). Maritime strategy of Indonesia in 2000-2010. In J. Schwarz, W. A. Herrmann, \& B. Seller (Eds.), Maritime Strategies in Asia (pp. 325-337). Bangkok: White Lotus Press.

Marsetio. (2014). Sea power Indonesia (Pertama). Jakarta: Universitas Pertahanan.

McCaffrie, J. (2006). Positioning navies for the future: Challenge and response. In J. McCaffrie (Ed.), Proceedings of the Royal Australian Navy Sea Power Conference 2004 (p. 274). New South Wales: Sea Power Centre-Australia and Halstead Press.

Melda, K. A. (2009). Maritime security in South East Asia: Indonesian. HeinOnline, (May), 88-102. Retrieved from https:// www.copyright.com/ccc/basicSearch.do? \&operation $=$ go\&searchType $=0$ 
Menon, R. (1998). Maritime strategy and continental wars (First). London: Frank Cass.

Mière, C. Le. (2013). A maritime school of strategic thought. In J. Jones (Ed.), A maritime school of strategic thought for Australia: perspectives (pp. 75-79). Sea Power Centre - Australia. doi: 10.1080/19480881.2014.882116

Morrison, D. (2011). Speech to RAN maritime conference. Retrieved April 18, 2017, from http://103.11.78.168/ /media/ Files/Speeches/Speech_to_Maritime_ Conference.pdf

Nor Azizan, I., \& Zarina, O. (2009). From "non-interference" to "constructive engagement": Contemporary MalaysiaMyanmar relations. Tamkang Journal of International Affairs, XII(IV), 1-42. http:// dx.doi.org/ 10.6185/TJIA.V

Percy, S. (2013). Maritime strategy in a world of pervasive insecurity. In A. Forbes (Ed.), Naval diplomacy and maritime power projection maritime power projection (pp. 121-133). Sea Power Centre - Australia. Canberra, Australia: Sea Power Centre-Australia.

Rotte, R. (2002). Maritime strategy of Singapore. In J. Schwarz, W. A. Herrmann, \& H.-F. Seller (Eds.), Maritime strategies in Asia (pp. 391-410). Bangkok: White Lotus Press.

Rubel, R. C. (2015). The home fleet: Pivot of maritime strategy. Corbett Paper, 16(4), 17.

Salim, C. (2015). A pathway to Indonesia's maritime future: the role of maritime policy, doctrine and strategy. Canberra: Sea Power Center-Australia. Retrieved from http://www.navy.gov.au/sites/ default/files/documents/Soundings_ No_5.pdf

Scott, H. B. M. (2004). Australia's maritime strategy. Parliament of Australia. Canberra. Retrieved from http://www. aph.gov.au/parliamentary_business/ committees/house_of_representatives_ committees?url=jfadt/maritime/report. htm

Sebastian, L. C., Supriyanto, R. A., \& Arsana, I. M. A. (2014). Indonesia and the Law of the Sea: Beyond the archipelagic outlook. In C. B. Roberts, A. D. Habir, \& L. C. Sebastian (Eds.), Indonesia at Home and Abroad Economics, Politics and Security (p. 125). Canberra: The Australian National University.

Setianegara, H. (2014). Strategi maritim pada perang laut nusantara dan poros maritim (Pertama). Yogyakarta: Leutikaprio.

Speller, I. (2005). Naval Diplomacy: Operation Vantage, 1961. In I. Speller (Ed.), The Royal Navy and Maritime Power in The Twentieth Century (pp. 164-180). New York: Frank Cass.

Sugiarto, P., Anna, Y. H., \& Adi, J. P. (2017). Potential conflict among ASEAN member states in the implementation of The ASEAN Economic Community. Jurnal Ilmu Sosial dan Ilmu Politik, 20(3), 236-248. doi: 10.22146/jsp.27208

Suropati, U., Sulaiman, Y., \& Montratama, I. (2016). Arungi samudra bersama sang naga: sinergi poros maritim dunia dan jalur sutra maritim abad ke-21. Jakarta: PT Gramedia Jakarta.

Swartz, P. M. (2005). US Navy Capstone strategies \& concepts (1974-2005). Retrieved November 4, 2017, from http://ibiblio.org/ hyperwar/NHC/Capstone/USN Strategies and Concepts - 1974-2005/USN Strategies and Concepts - 1974-2005.html

Taylor, P. D. (2008). Perspectives on maritime strategy. (P. D. Taylor, Ed.). Newport, Rhode Island: Naval War College Press.

Till, G. (1984). Maritime Strategy and the Nuclear Age (second). London: Macmillan Academic and Professional Ltd.

Till, G. (1994). Maritime strategy and the twenty - first century. Strategic Studies, 17(1), 176-199. doi: 10.1080/01402399408437545 
Till, G. (2005). Sea power a guide for the TwentyFirst Century. London: Frank Cass.

Till, G. (2006). Corbett and the emergence of a British school? In G. Till (Ed.), The Development of British Naval Thinking (pp. 60-88). New York: Routledge Taylor \& Francis Group.

Till, G. (2008). Maritime strategy and the Twenty-First Century. Journal of Strategic Studies, 17(1), 176-199. doi: 10.1080/01402399408437545

Till, G. (2009). Seapower a guide for the TwentyFirst Century (Kedua). Oxon: Routledge Taylor \& Francis Group.

Till, G. (2013). A maritime strategy for Australia. In J. Jones (Ed.), A maritime school of strategic thought for Australia: perspectives (pp. 58-61). Sea Power Centre - Australia.

Till, G. (2015). Indonesia as a growing maritime power: Possible implications for Australia. Soundings, (4), 11. Retrieved from http:// www.navy.gov.au/sites/default/files/ documents/Soundings_No_4.pdf
Turner, V. A. S. (2001). Missions of The U.S. Navy Sea Control Study Navy. CIA.

U.S. Navy. (2015). A cooperative strategy for 21st century Seapower. Retrieved from https:// www.uscg.mil/seniorleadership/DOCS/ CS21R_Final.pdf

Vego, M. (2009). Naval Classical Thinkers and Operational Art. Newport: Naval War College United States.

Wiley, J. (2016). America, Sea Power, and the World. (J. C. Bradford, Ed.) (First). Chichester: Wiley Blackwell.

Williams, J. (2008). Mahan, Corbett, Douhet and Mitchell: The naval and air theorists. Retrieved January 23, 2017, from https:// severalfourmany.files.word press. com/2015/09/mahan-corbett-douhet-andmitchell.pdf

Zarina, O., Nasuha, N. R. N. A. J., \& Halim, A. M. (2013). Non-Traditional Security Issues and the Stability of Southeast Asia. Jurnal Kajian Wilayah LIPI, 4(2), 150-164. doi: 10.14203/jkw.v4i2.265 